\title{
LINKING PERCEIVED SOCIAL SUPPORT TO SOCIAL ENTREPRENEURIAL INTENTION: THE MEDIATING ROLE OF ATTITUDE BECOMING SOCIAL ENTREPRENEUR
}

\author{
Purbo Jadmiko \\ Department of Management, Universitas Bung Hatta, Indonesia \\ purbojadmiko@bunghatta.ac.id
}

\begin{abstract}
The present study aims at identifying the social entrepreneurial intention among undergraduates students in Bung Hatta University context by using the theory of planned bahaviour as the research framework. A 10-questionnaire was responded by 150 studens of Bung Hatta University. The data were collected by purposive random sampling method. The questions measured perceived social support, attitude towards becoming a social entrepreneur, and social entrepreneurial intention. The result shows that attitude towards becoming a social entrepreneur full mediation between perceived social support to social entrepreneurial intention. Perceived social support and attitude towards becoming a social entrepreneur showed the positive significant relationship with social entrepreneurial intentions. This research study contributes to the social entrepreneurship literature by introductiong perceived social support and attitude towards becoming a social entrepreneur as antecedents that also explains social entrepreneurial intention formation.
\end{abstract}

Keywords: Perceived social support, attitude towards becoming a social entreprenuer (ATB), social entrepreneurial intention, the theory of planned behaviour

\section{A. INTRODUCTION}

The increasing global population, the expansion of trade and the exploitation of natural resources provide an increase in the sustainability of life. The issue of protecting businesses that are still against the law on the environment and social needs special attention. This makes the role of business entrepreneurs not an option for a supported future (Bocken et al., 2014). Therefore, to overcome these problems a new way of doing business that is maintained is very necessary. Supported business models get innovative to bring about the changes requested through the conceptualization of the company's mission and social added value (Boons \& Lüdeke-freund, 2013).

The issue of social entrepreneurship is currently a subject of study and study by researchers. Entrepreneurship considers social as a new phenomenon as a field of research. Social entrepreneurship is the answer to social problems that occur. The concept of social entrepreneurship is very different from business entrepreneurship. Business entrepreneurs only rely on profits and customer satisfaction, in contrast to social entrepreneurship more to social goals / social values (Mair et al., 2006). According to Utomo (2014), social entrepreneurs focus on seeing problems become opportunities (community empowerment becomes a new business model).

Hibbert et al. (2005) revealed what is meant by social assistance is to use entrepreneurship that is more oriented towards social goals and is not in accordance with profits, or the profits obtained are used for social purposes. Meanwhile, according to Mair et al., (2006) the concept of social entrepreneurship regarding business that demands a social mission or nonprofit sector. Social entrepreneurship is a term used to discuss innovative ways to overcome social problems (Desa, 2010). Social entrepreneurs are to fulfill their social mission (Abusaifan, 2012).

Mission and creating social value are key objectives of social entrepreneurship. This is confirmed by the resolution by Hulgard (2010) that social entrepreneurship defines social value created by collaboration with people and organizations from the general public who are also involved in social innovation economic activities. The definition of Hulgard (2010) as mentioned as social entrepreneurship consists of four main elements containing social values, 
civil society, innovation, and economic activity: 1) social value is a key element of social entrepreneurship that provides social benefits for the community and the surrounding environment; 2) civil society supports the collaboration and participation of civil society by optimizing social capital; 3) innovations that contribute socially in social solutions in innovative ways such as combining local wisdom and social innovation; and 4) economic activity is a balance between social mission and business activity that cannot be separated from between.

Regarding social entrepreneurship being a unique issue and phenomenon in the field of research, but there has not been much research discussing social entrepreneurial intentions (social entrepreneurial intentions) among students. The intention of social entrepreneurship among students becomes important as the role of students as agents of change. In addition, the melenial generation is now growing digitalization and automation that makes it possible to create social mission and value through social business innovation.

Furthermore, there are several studios on entrepreneurial interests that use the Planned Theory of Behavioral Theory (Ajzen, 1991) as a formulation that requires conceptual research. Planned Behavior Theory Perspective is the process of planning one's behavior planning before acting. The Theory of Planned Behavior Perspective also shows that there is a difference between the behavior carried out by the antecendent variable, but mediated (mediator) by the intention of one's attitude (Tiwari, et al., 2017b). Thus, studies on social entrepreneurial intentions are considered inconsistencies in formulating research models. However, there are studios where Perception of Social Support, direct influence and perception of direct social influence (direct effect) on social entrepreneurial intentions (Hockerts, 2017). This inconsistency is a gap of this research, whether the influence of the antecedent variable indirect effect on social entrepreneurial intentions. This study aims to prove the results of research on social entrepreneurial intentions among students.

\section{Perceived social support, attitude towards becoming a social entrepreneur and social entrepreneurial intention}

Perceived social support is another important antecedent that prompts the formation of behavioral intentions to start social enterprises (Mair and Noboa, 2006). Social support is vital for it helps an individual in attaining specific social entrepreneurial outcome (Hockerts, 2015). The study Lacap et. al., (2018) showed that university students' social entrepreneurial perceived social support are significantly and positively related to social entrepreneurial intention (the case of Filipino and Indonesian university students). This result indicates that the presence of social entrepreneurial perceived social support among university students will trigger their social entrepreneurial intention. Mair and Noboa (2006) and Hockerts (2017) also found out that social entrepreneurial perceived social support predict social entrepreneurial intent. Therefore, the reserchers hypothesize:

$\mathrm{H}_{1}$ : Perceived social support positively effect social entrepreneurial intention

$\mathrm{H}_{2}$ : Perceived social support positively effect attitude towards becoming a social entrepreneur

\section{Attitude towards becoming a social entrepreneur (ATB) mediating between perceived social support and social entrepreneurial intention}

Furthermore, in the context of indirect research, researchers use the foundation of the Planned Behavior Theory model (Ajzen, 1991) to formulate a conceptual framework. According to Krueger (1993), researchers emphasize that the antecedents that influence social entrepreneurial intention are indirect, but that influence influences attitudes first and then influences social entrepreneurial intention. 


\section{Figure 1. Planned Behaviour Theory}

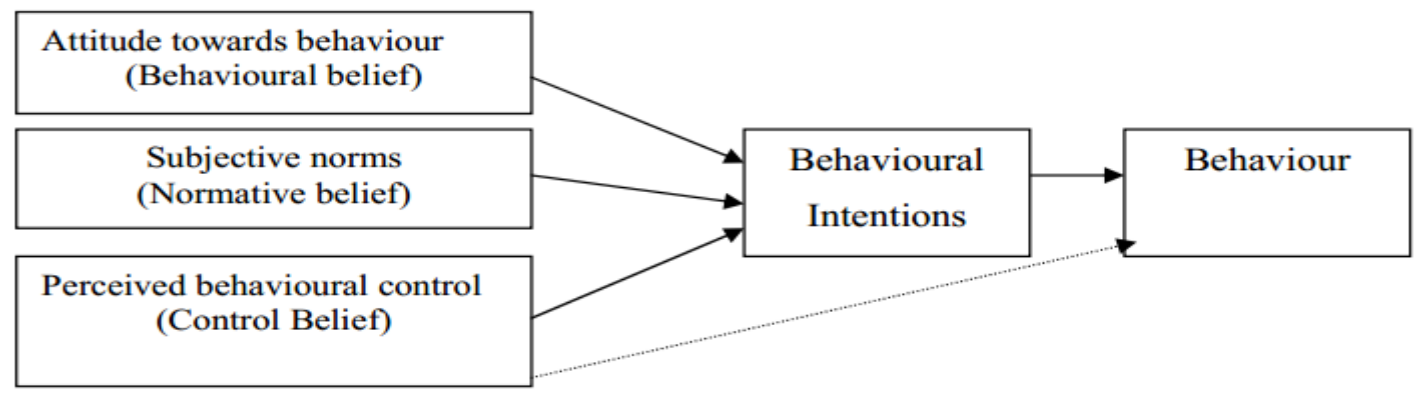

Source: Ajzen (1991)

The Planned Behavior Theory Model by Ajzen (1991) says that a person's actions are followed by an assessment of consciousness to act in a certain way. The Planned Behavior Theory model is an extension of the Theory of Reasoned Action (TRA) where it is explained that a person's intention towards behavior is formed by two main factors namely attitude toward the behavior and subjective norm (Ajzen, 1975). According to Ajzen, there are three determinants of intention to act namely attitudes toward behavior; Subjective norms and perceived behavioral control. Attitude is a factor found in a person who is studied to provide a positive or negative response to the assessment of something given. Subjective norms are perceptions arising from someone about the thoughts of others who will support or not support them in carrying out an action or something. While behavior control is a person's perception of youth or difficulty in carrying out a behavior.

\section{Figure 2. A model of social entrepreneurial intention formation}

Cognitive

Emotional

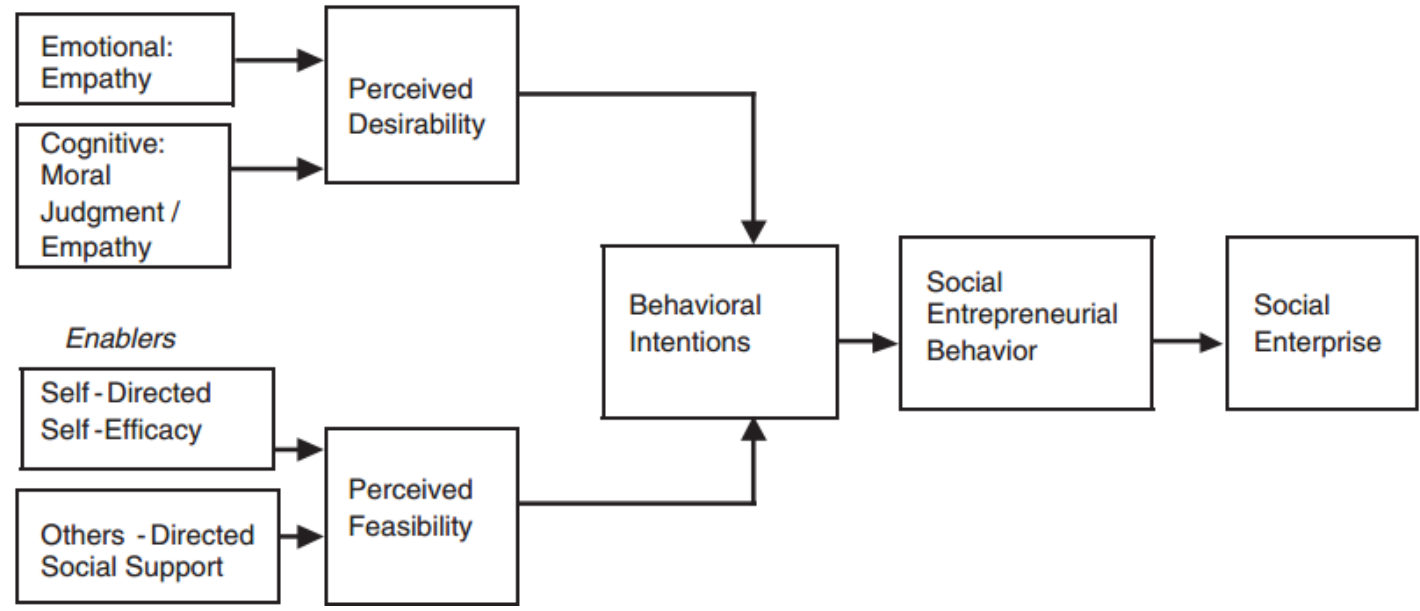

Source: Mair dan Noboa (2006)

Furthermore, the first attempt to develop a model that can capture the formation of social entrepreneurial intention models was carried out by Mair \& Naboa (2006). The model uses individual variables to measure intentions. In the Mair and Noboa model (2006) also suggested that the intention to start a social enterprise develops from perception to desire, which is influenced by the emotional cognitive construct that consists of Perceived Social Support as an emotional factor and moral judgment as a cognitive factor and perception is likely to be done (perceived feasibility) is influenced by moral judgment as a cognitive factor; and the perceived worth is influenced by someone or something that allows something to happen (enablers) consisting of self-efficacy and social support.

Research conducted by Mohammed, et al., (2017) found that Attitude toward behavior had a positive effect on social entrepreneurial intention in Algeria's Tlemcen University 
students. According to him, the results are based on the Planned Behavior Theory Model that has succeeded in understanding entrepreneurial intentions among students. Mohammed also added that positive attitudes and subjective norms on students increase positive intentions to establish new companies in the social field. Furthermore, (Jadmiko, 2019) also shows similar results that attitude toward becoming a social entrepreneur is positively and significantly effects social entrepreneurial intention. Based on the description then the third and fourth hypotheses are proposed as follows:

$\mathrm{H}_{3}$ : Attitude toward becoming a social entrepreneur positively effect social entrepreneurial intention

$\mathrm{H}_{4}$ : Attitude toward becoming a social entrepreneur mediates the positive relationship between perceived social suport with social entrepreneurial intention

Figure 3. Research Framework

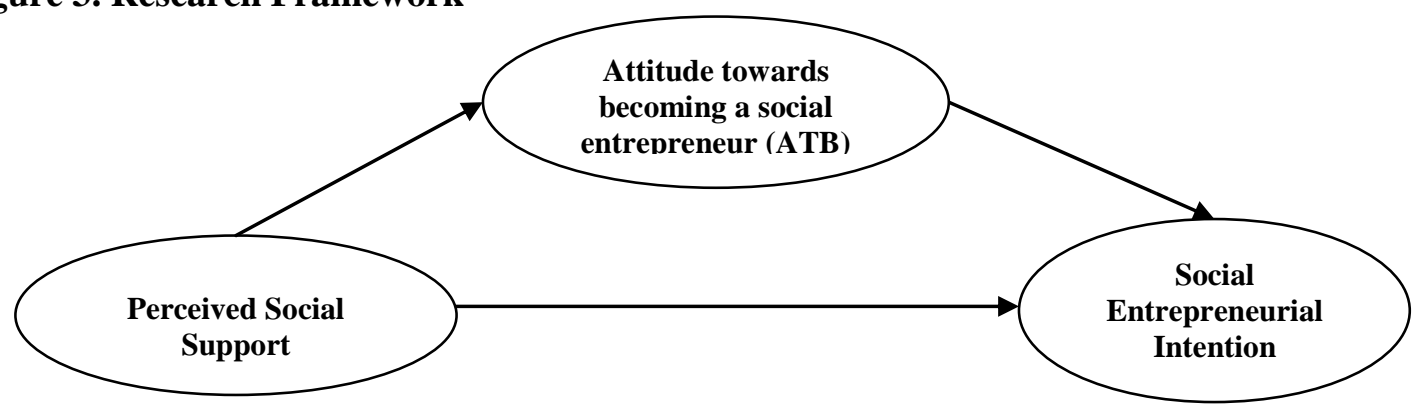

\section{B. RESEARCH METHOD}

This research method uses quantitative methods through surveys. The survey method is one of the primary data collection methods that can be done carefully, systematically and structured (Cooper \& Schinder, 2014). The population of this research is the students of the Faculty of Economics and Business, Bung Hatta University. The sampling method uses purposive sampling with criteria that are students who have taken at least 2 semester $(n=150)$.

Table 1. Operational Definitions of Variables

\begin{tabular}{|c|c|c|c|}
\hline No & Variable & Definition & Indicator \\
\hline 1 & $\begin{array}{l}\text { Perceived Social } \\
\text { Support }\end{array}$ & $\begin{array}{l}\text { Felt that they would be able to tap } \\
\text { into formal and informal support } \\
\text { networks should they decide to throw } \\
\text { themselves into } \\
\text { venture(Hockerts, 2015) }\end{array}$ & $\begin{array}{l}\text { 1. Solve social problems } \\
\text { 2. Support from people } \\
\text { to star social } \\
\text { organization } \\
\text { 3. Receive much support } \\
\text { if I were to start a } \\
\text { social enterprise }\end{array}$ \\
\hline 2 & $\begin{array}{l}\text { AttitudeToward } \\
\text { becoming a Social } \\
\text { Entrepreneur } \\
\text { (ATB) }\end{array}$ & $\begin{array}{l}\text { The extent to which a person has a } \\
\text { positive or negative assessment of } \\
\text { social entrepreneurship as a career } \\
\text { choice (Tiwari et al., 2017a) }\end{array}$ & $\begin{array}{l}\text { 1. Social career } \\
\text { 2. Social business } \\
\text { 3. Social business } \\
\text { satisfaction } \\
\text { 4. Benefits of social } \\
\text { enterprise }\end{array}$ \\
\hline 3 & $\begin{array}{l}\text { Social } \\
\text { Entrepreneurial } \\
\text { Intention }\end{array}$ & $\begin{array}{l}\text { One's belief in desires, determination } \\
\text { to set up a social enterprise } \\
\text { (Hockerts, 2015) }\end{array}$ & $\begin{array}{l}\text { 1. Contribution of social } \\
\text { problems } \\
\text { 2. The intention to } \\
\text { establish a social } \\
\text { enterprise }\end{array}$ \\
\hline
\end{tabular}

Validity testing uses confirmatory factor analysis (CFA). According to Hair et al. (2010) the requirements for loading factor checks are: loading 0.30 is considered to have met the minimum level; loading 0.40 is considered better; and for loading $\geq 0.50$ is considered to be 
practically significant. While reliability testing uses Cronbach's alpha analysis techniques. According to Hair et al. (2010), if the Cronbach's alpha coefficient shows a value of $\leq 0.60$, the reliability is considered poor, but can still be used for further. Then, if the Cronbach's alpha coefficient shows a value between 0.60 to 0.70 then reliability can be accepted, then if Cronbach's alpha coefficient shows a value $\geq 0.80$ then reliability is considered good.

\section{RESULT AND DISCUSSION}

The first stage before testing a hypothesis is to test the research instrument. Testing of research instruments using the CFA method aims to ensure that the question items that have been designed are valid. Next, the Kayser-Meyer-Olkin Measure of Sampling Adequacy (KMO) method and Bartlett's Test of Sphericity are used to evaluate the strength of linear associations between items in the correlation matrix. A KMO score>0.50 is considered acceptable and indicates that the factor analysis test is worth further analysis. As shown in Table 2, the KMO score $=0.777$ (Bartlett's Test of Sphericity: Approx. Chi-Square $=503,010, \mathrm{df}=45 \mathrm{Sig}$. At $\mathrm{p}$ $<0,000)$ for the research model, which involved items measuring the perceived social support variable , ATB and social entrepreneurial intention. Based on the KMO value $\geq 0.5$, it is concluded that the analysis can proceed to the next stage.

Table 2. Score of KMO's

\begin{tabular}{lll}
\hline Kayser-Meyer-Olkin & Measure of &, 777 \\
Sampling Adequacy & & \\
Bartlett's Test of & Sphericity: & 503,010 \\
Approx. Chi-Square & & \\
$d f$ & 45 \\
Sig. &, 000 \\
\hline Source: Data(2020) &
\end{tabular}

After assuming the KMO value is fulfilled, then the validity test is performed. Testing using the CFA method. Based on the results of the CFA test, obtained from a total of 11 instruments, only 10 items were at a loading factor value $\geq 0.5$ which indicates valid. While 1 item was declared invalid namely SEI3 due to loading factor $\leq 0.5$. Furthermore, these items are not included (outliers) at the next analysis stage. Furthermore, based on the results of testing the reliability of statement items that have been declared valid. In general, based on Table 3 , the perceived social support and ATB variables have shown that the Cronbach's Alpha adequacy value is nilai 0.6 while the social entrepreneurial intention variable is declared less reliable but can still be included at the analysis stage (Hair et al., 2010 ).

Table 3. Validity Test with CFA

\begin{tabular}{|c|c|c|c|c|}
\hline \multicolumn{4}{|c|}{ Rotated Component Matrix } & \multirow[t]{3}{*}{ Reliability } \\
\hline \multirow{2}{*}{ Items } & \multicolumn{3}{|c|}{ Component } & \\
\hline & 1 & 2 & 3 & \\
\hline PSS1 & 7,78 & & & \\
\hline PSS2 &, 88 & & & 0,761 \\
\hline PSS3 &, 80 & & & \\
\hline SEI1 & & ,838 & & \\
\hline SEI2 & & 81 & & 528, \\
\hline ATB1 & & & ,716 & \\
\hline ATB2 & & & ,781 & \\
\hline ATB3 & & & ,792 &, 825 \\
\hline ATB4 & & &, 835 & \\
\hline ATB5 & & & 734 & \\
\hline
\end{tabular}


The test results are shown in Table 5 that perceived social support has a positive effect on social entrepreneurial intention because the sig. at $\mathrm{p} \geq 0.05$ ie $0,000\left(\mathrm{H}_{1}\right.$ supported). These results show that the social support perceived by students has a positive effect on social entrepreneurial intention. That is, the higher the social support received by students, the higher their intention to become a social entrepreneur.

Furthermore, the results of testing the $\mathrm{H}_{2}$ hypothesis that perceived social support has a positive effect on ATB shows the value of Sig. at $\mathrm{p} \leq 0.05$ which is 0,000 (H2 supported). Based on the regression coefficient shows that perceived social support affects $48.6 \%(0.486)$ of ATB. That is, perceived social support perceived by someone has a positive effect on ATB. The higher perceived social support received by students, the higher the ATB perceived. Finally, testing the $\mathrm{H}_{3}$ statement that ATB has a positive effect on social entrepreneurial intention shows the value of Sig. at $\mathrm{p} \leq 0.05$ which is $0,000\left(\mathrm{H}_{3}\right.$ supported $)$. Based on the regression coefficient shows that perceived social support affects $18 \%(0.180)$ of ATB. This finding confirms the revelation of the $\mathrm{H} 3$ hypothesis that student ATB has a positive effect on student intention to become social entrepreneurial. The higher ATB perceived by someone, the higher one's interest in social entrepreneurship.

Table 5. Results of Regression Test

\begin{tabular}{|c|c|c|c|c|}
\hline Hypotesis & $\begin{array}{l}\text { Unstandardized } \\
\text { Beta Coefficients }\end{array}$ & Sig. & Adjusted $\mathbf{R}^{2}$ & $\mathbf{F}$ \\
\hline $\begin{array}{ll}\mathrm{H}_{1} & \begin{array}{l}\text { Perceived Social Support } \rightarrow \text { Social } \\
\text { Entrepreneurial Intention }\end{array}\end{array}$ & 0,216 & 0,000 & 0,033 & $6,334 *$ \\
\hline $\mathrm{H}_{2}$ Perceived Social Support $\rightarrow$ ATB & 0,486 & 0,000 & 0,074 & $13,336^{*}$ \\
\hline $\begin{array}{ll}\mathrm{H}_{3} & \begin{array}{l}\mathrm{ATB} \rightarrow \\
\text { Intention }\end{array}\end{array}$ Social Entrepreneurial & 0,180 & 0,000 & 0,075 & $13,563^{*}$ \\
\hline
\end{tabular}

Note: *Significant at $p<0,01$

Source: Data (2020)

The next stage of the analysis is testing the effect of the mediator variable, ATB, on the relationship between perceived social support and social entrepreneurial intention. At this stage, this study uses a mediating variable testing method developed by Baron \& Kenny (1986). The method is based on several basic assumptions that must be met. The assumptions are; 1) The independent variable $(\mathrm{X})$ with the mediator variable $(\mathrm{M})$ shows a significant relationship; 2) The relationship between the mediator variable $(\mathrm{M})$ and the dependent variable $(\mathrm{Y})$ must also be significant; 3 ) The relationship between the independent variable $(X)$ and the dependent variable $(\mathrm{Y})$, is significant; and 4) The relationship between the independent variable $(\mathrm{X})$ with the dependent variable $(\mathrm{Y})$ and the relationship between the mediator variable $(\mathrm{M})$ and the dependent variable $(\mathrm{Y})$ shows the mediating effect. Full mediation when $\mathrm{X}$ with $\mathrm{Y}$, is not significant and $\mathrm{M}$ with $\mathrm{Y}$, is significant. No mediation when $\mathrm{X}$ with $\mathrm{Y}$, significant and $\mathrm{M}$ with $\mathrm{Y}$, not significant. Partial mediation when $\mathrm{X}$ with $\mathrm{Y}$, significant and $\mathrm{M}$ with $\mathrm{Y}$, significant.

Table 6 shows the results of testing the hypothesis statement $\mathrm{H}_{4}$ that ATB mediates the effect between perceived social support on social entrepreneurial intention by using the testing procedure (Baron \& Kenny, 1986). The results of hypothesis testing $\mathrm{H}_{4}$ show full mediation (full mediation), that is the influence between Perceived Social Support on social entrepreneurial intention is not positive and significant after it is included in the mediating variable regression model. That is, this confirms the results of testing the $\mathrm{H}_{1}$ hypothesis thatthe effect of the perceived social support variable does not directly influence the social entrepreneurial intention but the effect is fully mediated by the ATB variable. So it can be concluded that the $\mathrm{H}_{4}$ statement is supported. The results of the summary of $\mathrm{H}_{4}$ testing with the mediating variabe testing procedure by Baron \& Kenny (1986) are shown in Table 6.

Table 6. Results of the Mediation Hypothesis

\begin{tabular}{|c|c|c|c|c|c|c|}
\hline Hypotesis & 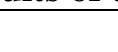 & 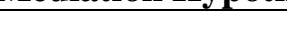 & $B$ & Sig. & $\mathbf{F}$ & Results \\
\hline $\begin{array}{l}\text { Stape I } \\
\text { Perceived }\end{array}$ & Social & Support $\rightarrow$ Social & 0,216 & 0,000 & $6,334^{*}$ & \\
\hline
\end{tabular}




\begin{tabular}{|c|c|c|c|}
\hline Entrepreneurial Intention & & & \\
\hline $\begin{array}{l}\text { Stape II } \\
\text { Perceived Social Support } \rightarrow \text { ATB }\end{array}$ & 0,486 & 0,000 & $13,336^{*}$ \\
\hline $\begin{array}{l}\text { Tahap III } \\
\text { ATB } \rightarrow \text { Social Entrepreneurial Intention } \\
\text { Stape IV }\end{array}$ & 0,180 & 0,000 & $13,563 *$ \\
\hline $\begin{array}{l}\text { Perceived Social Support } \\
\text { ATB } \rightarrow \text { Social Entrepreneurial Intention }\end{array}$ & $\begin{array}{l}0,139 \\
0,157\end{array}$ & $\begin{array}{l}0,111 \\
0,002\end{array}$ & 8,138 \\
\hline
\end{tabular}

\section{Last Stape}

Perceived Social Support $\rightarrow$ ATB $\rightarrow$ Social

Full

Entrepreneurial Intention

Mediation

\section{Discussion}

Note: *Significant at $p<0,01$

Source: Data (2020).

The results of testing the H1 hypothesis statement showed support. These findings are consistent with the results of research conducted by Hockerts (2015) where Perceived Social Support was found to have a positive effect (direct effect) on social entrepreneurial intention. Furthermore, the $\mathrm{H} 2$ test results where the hypothesis statement that is perceived social support has a positive effect on ATB shows supported. The results of this study confirm that perceived social support received by students can significantly influence attitudes towards ATB.This is consistent with the results of the study Jadmiko (2019) The higher the level of perceived social support, the more it shows its concern for social problems which is then intended in an attitude to intend to become a social entrepreneur. These results are in line with the views of Mair \& Naboa (2006) and Hockerts (2015) that Perceived Social Support also acts as an individual attitude towards the behavior of social entrepreneurs.

Furthermore, the results of testing the hypothesis statement that Perceived Social Support has a positive effect on ATB in line with the mission and creation of social value from social entrepreneurship (Hulgard, 2010). Perceived Social Support is perceived by someone as encouraging someone to behave and contribute in solving the problem. The higher the level of social support received, the more one will behave to participate in solving the problem by establishing a business or business that is not only business oriented, but also oriented towards social mission.

At the stage of testing the $\mathrm{H}_{3}$ hypothesis that ATB has a positive effect on social entrepreneurial intention showing support. This finding shows that the element of attitude towards interest in becoming a social entrepreneur has a positive and significant effect on a person's intention to become a social entrepreneur. The higher the attitude a person shows to be a social entrepreneur, the higher his interest in becoming a social entrepreneur. The attitude perceived by someone will be an important factor in increasing interest in becoming a social entrepreneur. These results are in line with research findings of Tiwari et al., (2017a) and (Mohammed et al., 2017) that social entrepreneurial intention is influenced by ATB. These results are consistent with research findings by Tiwari et al., (2017a) where the role of attitudes towards entrepreneurial behavior has a direct and positive effect on social entrepreneurial intention. This condition reflects that the higher the attitude perceived by someone, the higher their intention to set up a business or social business. This finding is also the implication of the planned theory of behavior model in which a person's intentions are driven by the presence of an element of attitude that someone perceives.

Furthermore, ATB mediation testing on the influence between Perceived Social Support on social entrepreneurial intention shows supported. Based on the mediation testing procedure developed by (Baron \& Kenny, 1986) it was found that ATB mediates in full (full mediation) the influence between Perceived Social Support on social entrepreneurial intention (see Table $6)$. These findings confirm the social entrepreneurial intention formation model developed by Mair \& Naboa (2006). Mair and Noboa develop a model that the intention to start a social 
enterprise develops from perception to desire, which is influenced by emotional cognitive constructs that consist of Perceived Social Support as emotional factors and moral judgment as cognitive factors and perception of the likelihood of being perceived (influenced feasibility) is influenced by valuation moral as a cognitive factor; and the perceived worth is influenced by someone or something that allows something to happen (enablers) consisting of self-efficacy and social support.

\section{CONLUSIONS AND IMPLICATIONS}

The results of hypothesis testing indicate that toward becoming full mediation social entrepreneur (ATB) between perceived social support on social entrepreneurial intention (indirect effect). Other findings show that attitudes toward interest in becoming social entrepreneurs have a significant positive effect on social entrepreneurial intention. The results of this study contribute to the process of forming one's intention to become a social entrepreneur, especially among students.

Practically, Bung Hatta University is advised to be able to redesign curriculum content especially in entrepreneurship courses from becoming an entrepreneur (businessman) in order to start developing a curriculum that is charged about growing social entrepreneurial intention. Curriculum design needs to be linked to aspects of community problems both micro and macro so that students can be equipped with insights and experiences to become social entrepreneurs who are not only focused on business. Where we know that the role of social entrepreneurs is seen as important in contributing to empowering the community and participating in solving social and economic problems where the government may not be able to solve the problem alone. In addition, empowerment that is utilized directly by the community is a form of social responsibility that must be implemented as an tangible form of the Tridharma of Higher Education, namely community service. In addition to the tertiary level, the government is also expected to participate in growing social entrepreneurial intention since high school or vocational high school so that more social entrepreneurs participate in solving social problems.

The object of this research is only in the context of Bung Hatta University's economics and business faculty so the generalization of research findings needs to be improved by broadening the scope of the research object by involving more other universities. The social entrepreneurial intention instrument in this study only consists of 3-item statements, future research in order to determine the construct of social entrepreneurial intention better in measuring these variables. Therefore, further research is suggested to examine other factors on social entrepreneurial intention variables by using the Mair \& Naboa (2006) model such as cognitive emotional constructs consisting of perceived social support as emotional factors and moral judgment as cognitive factors and perceptions are likely to be carried out ( perceived feasibility) is influenced by moral judgment as a cognitive factor; and the perceived worth is influenced by someone or something that allows something to happen (enablers) consisting of self-efficacy and social support. On the other hand, further research also needs to examine the variable of emotional intelligence where in that dimension there is also an element of perceived social support.

\section{E. REFERENCES}

Abu-saifan. (2012). Social Entrepreneurship: Definition and Boundaries. Technology Innovation Management Review, 2(2), 22-27.

Ajzen, I. (1975). Belief, attitude, intention and behaviour: An introduction to theory and research. Reading, MA: Addison-Wesley. Reading, MA: Addison-Wesley.

Ajzen, I. (1991). The theory of planned behavior. Organizational Behavior and Human Decision Processes, 50(2), 179-211.

Baron, R. M., \& Kenny, D. A. (1986). The Moderator-Mediator Variable Distinction in Social Psychological Research: Conceptual, Strategic , and Statistical Considerations, 51(6), 1173-1182. 
Bocken, at al. (2014). A literature and practice review to develop sustainable business model archetypes A literature and practice review to develop sustainable business model. Journal of Cleaner Production, 65(February), 42-56. doi:10.1016/j.jclepro.2013.11.039

Boons, F., \& Lüdeke-freund, F. (2013). Business models for sustainable innovation: state-ofthe-art and steps towards a research agenda. Journal of Cleaner Production, 45, 9-19. doi:10.1016/j.jclepro.2012.07.007

Desa, G. (2010). of a Research Field in Emergence. In Values and Opportunities in Social Entrepreneurship (pp. 6-28). Palgrave Macmillan, a division of Macmillan Publishers Limited.

Cooper,Donald., Schinder, P. (2014). Business research methods. McGraw-Hill Companies, New York.

Hair, F. (2010). Multivariate Data Analysis. 7th ed. Upper Saddle River, NJ: Prentice Hall.

Hockerts, K. (2015). Antecedents of Social Entrepreneurial Intentions: A Validation Study The Social Entrepreneurial Antecedents Scale ( SEAS ): A Validation Study. Social Enterprise Journal, 11(3), 260-280. doi:10.5465/AMBPP.2013.16805abstract

Hockerts, K. (2017). Determinants of Social Entrepreneurial Intentions, 105-130. doi:10.1111/etap.12171

Hulgard, L. (2010). DISCOURSES OF SOCIAL ENTREPRENEURSHIP - VARIATIONS OF THE SAME THEME ?, (10), 1-21.

Jadmiko, P. (2019). Peran Pemediasi Attitude Becoming Social Entrepreneur ( Atb ) Pada Pengaruh Antara Empati. Jurnal Benefita: Ekonomi Pembangunan, Manajemen Bisnis \& Akuntansi, 4(September), 422-434. doi:10.22216/jbe.v4i3.4617

Krueger, N. (1993). The Impact of Prior Entrepreneurial Exposure on Perceptions of New Venture Feasibility and Desirability *, 5-21.

Lacap, Jean Paolo G., Mulyaningsih, Hendrati Dwi., Ramadani, Veland . (2018) "The mediating effects of social entrepreneurial antecedents on the relationship between prior experience and social entrepreneurial intent: The case of Filipino and Indonesian university students", Journal of Science and Technology Policy Management, https://doi.org/10.1108/JSTPM-03-2018-0028

Mair, J., Robinson, J., \& Hockerts, K. (2006). Social Entrepreneurship (p. 1).

Mohammed, B. S., Fethi, A., \& Djaoued, O. B. (2017). The Influence of Attitude, Subjective Norms and Perceived Behavior Control on Entrepreneurial Intentions : Case of Algerian Students, 7(6), 274-282. doi:10.5923/j.economics.20170706.02

Tiwari, P., Bhat, A. K., \& Tikoria, J. (2017a). Predictors of social entrepreneurial intention: an empirical study. South Asian Journal of Business Studies, 6(1), 1-25. doi:10.1186/s40497017-0067-1

Tiwari, P., Bhat, A. K., \& Tikoria, J. (2017b). The role of emotional intelligence and selfefficacy on social entrepreneurial attitudes and social entrepreneurial intentions, 0676(September). doi:10.1080/19420676.2017.1371628

Utomo, H. (2014). Menumbuhkan Minat Kewirausahaan Sosial. Among Makarti, 7(14), 1-16. 